\title{
Potential industrial utilization of starches extracted from new yellow cassava varieties
}

\author{
Ginette Gladys DOUE *, Rose-Monde MEGNANOU, Allah Antoine ASSAMOI and \\ Sebastien Lamine NIAMKE
}
Laboratoire de Biotechnologies, UFR Biosciences, Université Félix HOUPHOUET-BOIGNY, Université Félix HOUPHOUET-BOIGNY 22 BP 582 Abidjan 22, Côte d'Ivoire.
*Corresponding author, Email: doueginette@yahoo.fr, Tel: 0022507 582729

\begin{abstract}
Industrials generally utilize rice, wheat, corn and potato starches because of their well-known physicochemical and functional properties. In this study, starches of some improved cassava varieties were analyzed in order to detect those revealing potentialities and aptitude for industrial exploitation. For this, morphological, physicochemical and functional characteristics of these starches were evaluated. All the starches were composed of ovoid and conical granules with truncated sides bearing one or several holes. They contained relatively low amount of small granules $(<10 \mu \mathrm{m})$ with low amylopectin content. All starches showed very strong water absorption capacity with the strong value recorded by $\mathrm{V}_{53}(122.52 \pm 1.57 \%)$ and the lowest by $\mathrm{V}_{63}(104.84 \pm 0.55 \%)$ and began gelatinizing early $\left(50-55{ }^{\circ} \mathrm{C}\right)$. However, physicochemical and functional characteristics significantly varied from a starch variety to another. Hence, $\mathrm{V}_{53}(32.47 \pm 0.54 \mathrm{~g} / \mathrm{g})$, $\mathrm{V}_{63}(29.41 \pm 0.64 \mathrm{~g} / \mathrm{g})$ and $\mathrm{V}_{71}(28.58 \pm 0.55)$ varieties which recorded low small granules content showed the earliest $\left(80^{\circ} \mathrm{C}\right)$ and strongest swelling power peak. In addition, these varieties showed the lowest syneresis values at $4{ }^{\circ} \mathrm{C}\left(\mathrm{V}_{53}(0.01 \%)\right.$ and $\mathrm{V}_{63}(0.6 \%)$ and at $\left.-15{ }^{\circ} \mathrm{C} \mathrm{V}_{71}(0.01 \%)\right)$ during the first week of experimentation $\left(\mathrm{V}_{71}\right)$ and during the four weeks of experimentation $\left(\mathrm{V}_{53}\right.$ and $\left.\mathrm{V}_{71}\right)$. The highest values of paste clarity were highlighted by $\mathrm{V}_{23}(63.00 \pm 0.3 \%)$ and $\mathrm{V}_{53}(85.85 \pm 0.5 \%)$, respectively. All the studied cassava starches varieties showed interesting physicochemical and functional characteristics which could be exploited in food and non-food industries.
\end{abstract}

(C) 2013 International Formulae Group. All rights reserved.

Keywords: New yellow Cassava varieties, starches, physicochemical characteristics, functional properties, industrial utilization.

\section{INTRODUCTION}

Each year, about 60 million tons of starch are extracted from a wide range of cereal, root and tuber crops for use in a variety of products: as stabilizers in soups and frozen food, constituent for skin cosmetics, coating on pills and paper, adhesives on stamps and plywood, as stiffening agent in textiles, raw material for producing ethanol, and even as binder in concrete (Cereda et al., 1996; FAO/IFAD, 2004). However, for a product like starch, which is used as a basic material in such quite different branches of industry, 
quality can only be defined with reference to the end use (FAO, 2006).

About $10 \%$ of the starches occurring in industries comes from cassava (Manihot esculenta Crantz) roots. In many countries like Brazil, Canada, Japan and USA, it faces strong competition from maize (corn), wheat and potato starches which prices are stable because of their high consistent quality (Cereda et al., 1996). Moreover, in these countries, cassava starch is used only after being modified. Hence, cassava producing countries have to propose cassava varieties starches with better quality and potentialities than those currently proposed in order to be more competitive. In this aim, the Global Cassava Development Strategy, an initiative facilitated by IFAD (International Fund for Agricultural Development) and FAO, lead to highlight the importance of cassava starch which increased over the past 25 years (FAO/IFAD, 2004). This strategy was employed in Thailand where people made the transition from cassava as staple food to products and raw materials for processing industries. In Ecuador, starch extraction has become a major source of income for smallscale farmers (FAO, 2006). Inversely, in Africa where production average 100 million tons of roots a year, the starch extraction industry is virtually nonexistent except Nigeria and South Africa (Cereda et al., 1996; FAO/IFAD, 2004)

It is worth noting that in Africa like elsewhere, many new varieties of cassava have been proposed through IITA (International Institute of Tropical Agriculture) research programs in order to reach food self-sufficiency but also to transform cassava into more nutritive (bio fortification) food for high cassava consumers. Earlier studies on the fresh paste and the flour extracted from roots of some of these new cassava varieties have revealed a relatively high amount of starch and a wide range of potential household and industrial uses (Koua et al., 2012). However, for an objective and specific appointment to any industrial utilization, the physicochemical and functional properties of the starches of these new cassava varieties seemed essential and useful. The present study, included in a wide program for new cassava varieties valorization, aimed at detecting the industrial potentialities of starches extracted from seven new cassava varieties.

\section{MATERIALS AND METHODS Materials}

Cassava roots (11 month old) were obtained from the collection of the Agricultural Research Center (CNRA) (Abidjan, Côte d'Ivoire) on June 2012. Seven new cassava varieties encoded $V_{23}, V_{52}, V_{53}$, $\mathrm{V}_{62}, \mathrm{~V}_{63}, \mathrm{~V}_{65}$, and $\mathrm{V}_{71}$ (yellow colored pulp) were used in this study. All chemicals and standards used in this study were analytical grades.

\section{Starch extraction}

Cassava starches were extracted within 24 hours after harvesting according to Banks and Greenwood (1975) method. Samples of two kilograms $(2 \mathrm{~kg}$ ) of each cassava roots were washed, peeled and cut into small slices $(4 \times 4 \mathrm{~cm})$ with stainless steel knife. The slices were blended (Moulinex, France) and the paste dispersed in a sodium chloride (4\%, w/v) solution to separate proteins from the starch during $24 \mathrm{~h}$ at $25 \pm 1{ }^{\circ} \mathrm{C}$. The slurry was sieved successively through $500 \mu \mathrm{m}, 250$ $\mu \mathrm{m}$ and $100 \mu \mathrm{m}$ sieves. The starch was allowed to settle and the supernatant decanted off. Solids were washed with distilled water twice and centrifuged at $2660 \mathrm{rpm}$ for 15 minutes. The sample was then dried in an electric ventilated oven (Memmert 700, Germany) at $45{ }^{\circ} \mathrm{C}$ for $48 \mathrm{hrs}$. The dry products were manually ground in porcelain mortar, weighted and then stored in a sealed dried polyethylene bag for further analyses. 


\section{Starch granules morphology}

This parameter was determined by scanning electron microscope (FEG Supra 40 VP Zeiss 2008). A pinch of dehydrated starch was placed in a brass disk using double-sided adhesive silver-tape, coated with gold/palladium (60/40). The diameter distribution was then determined on 500 granules using a calibrated micrometer.

\section{Moisture content}

This parameter was determined following the AOAC (1990) procedure. pH value: $\mathrm{pH}$ value was carried out following Benesi et al. (2004) method. A 20\% (w/v) dispersion of the sample was shaken in water for $5 \mathrm{~min}$ and the $\mathrm{pH}$ value was recorded using a calibrated $\mathrm{pH}$ meter (EUTECH Instrument, Etats Unis).

\section{Amylose and amylopectin contents}

These parameters were determined following the method described by Jarvis and Walker (1993): Defatted starch (0.1g) was dissolved in $5 \mathrm{~mL}$ of potassium hydroxide (1N) solution. The suspension was thoroughly mixed and $5 \mathrm{~mL}$ of $\mathrm{HCl}(1 \mathrm{~N})$ solution were added. The mixture was boiled in water bath for $15 \mathrm{~min}$ and the volume was adjusted to 10 $\mathrm{mL}$. After centrifugation at $1000 \mathrm{rpm}$ for 10 min, the supernatant was used for determination of amylose and amylopectin. For this, $0.05 \mathrm{~mL}$ of the supernatant was introduced in a test tube and $4.85 \mathrm{~mL}$ of distilled water, following by $0.1 \mathrm{~mL}$ of iodine reagent were added. The mixture obtained was left to stand for $10 \mathrm{~min}$ and the absorbance was read at $580 \mathrm{~nm}$ and $720 \mathrm{~nm}$, respectively by using a spectrophotometer (Helios, Omega, UK). Standard curves of amylose $(5 \mathrm{mg} / \mathrm{mL})$ were used as references.

\section{Swelling power and solubility}

Swelling power (SP) and solubility were determined using $1 \%(\mathrm{w} / \mathrm{w})$ dry base starch dispersions according to $\mathrm{Li}$ and Yeh (2001) method. $0.1 \mathrm{~g}$ of starch (Ds) was weighted into a $15 \mathrm{~mL}$ graduated centrifuge tube. Distilled water was added to give a total of $10 \mathrm{~mL}$. The suspension was stirred sufficiently and heated at temperature varying from $50{ }^{\circ} \mathrm{C}$ to $95{ }^{\circ} \mathrm{C}$ in a water bath for 30 min with a constant stirring. The tubes were cooled at room temperature and centrifuged for $15 \mathrm{~min}$ at $4000 \mathrm{rpm}$. The supernatant was collected and dried at $100{ }^{\circ} \mathrm{C}$ for $24 \mathrm{~h}$. The weight of the sediment (Wse) and soluble material (Dsu) in the supernatant were determined. The swelling power (SP) and solubility (S) were calculated using the formulas as follow: SP (g/g Starch) $=$ Wse/Ds $\mathrm{S}(\% \mathrm{db})=100 \times \mathrm{Dsu} / \mathrm{Dse}$

\section{Water absorption capacity}

Sosulski (1962) method was used to evaluate water absorption capacity. Cassava starches suspension $(80 \%$, w/v) were dispersed in a pre-weighed centrifuge tubes. The tubes were agitated in a vortex mixer for $2 \mathrm{~min}$ and centrifuged at $400 \mathrm{rpm}$ for $20 \mathrm{~min}$. The supernatant was removed and the tube was then weighted. The result was expressed as the weight of water bound by $100 \mathrm{~g}$ dry starches.

\section{Refrigeration and freeze stability}

Stability of starches samples was determined according to Schoch (1968) method: Starch suspension $(4 \%, \mathrm{w} / \mathrm{v})$ was heated for $20 \mathrm{~min}$ at $100{ }^{\circ} \mathrm{C}$. Ten (10) $\mathrm{g}$ of paste sample (WG) were conditioned in a plastic tube, sealed tightly with parafilm and stored at $-15{ }^{\circ} \mathrm{C}$ and $4{ }^{\circ} \mathrm{C}$, respectively for 4 weeks.

\section{Syneresis after refrigeration}

Every 7 days, three tubes were taken out of the refrigerator and held at room temperature during $60 \mathrm{~min}$. Tubes were centrifuged at $2660 \mathrm{rpm}$ for $10 \mathrm{~min}$ and supernatant was separated and weighted (WS). Syneresis was calculated as follow: WS/WG x 100 


\section{Syneresis after freezing}

Every 7 days, three tubes were taken out of the freezer and held during $90 \mathrm{~min}$ in a water bath $\left(50^{\circ} \mathrm{C}\right)$. Samples were centrifuged (2660 rpm for $10 \mathrm{~min}$ ) and then supernatant was separated and weighted (WS).

\section{Paste clarity}

The methodology suggested by Craig et al. (1989) was used. A $1 \%(\mathrm{w} / \mathrm{v})$ dry base (db) aqueous dispersion of starch was boiled at 97 ${ }^{\circ} \mathrm{C}$ with shaking thoroughly every $5 \mathrm{~min}$ for 30 min. Transmittance was measured every week by using a spectrophometer (Helios, Omega, UK) at $650 \mathrm{~nm}$ after cooling to room temperature. Three different quantifications per starch sample were made and mean values were then calculated.

\section{Statistical analysis}

All the experiments were performed in triplicate and data were analyzed by using the XLSTAT version 2007 Software. In order to underline differences between means, the Duncan's test of the ANOVA was used at 95\% of confidence.

\section{RESULTS}

\section{Morphological characteristics}

Morphological characteristics (size and shape) were various. The granules size of the whole varieties ranged from 2.81 to $29.86 \mu \mathrm{m}$ (Table 1). The highest and the narrowest extent of variation in the granular structure were recorded respectively by $\mathrm{V}_{53}(6.46-$ $29.86 \mu \mathrm{m})$ and $\mathrm{V}_{62}(6.15-23.66 \mu \mathrm{m})$. All the starches contained both small and large granules. Nevertheless, the amounts of small granules were less important than those of the large ones (Table 1). The variety $\mathrm{V}_{65}$ showed the most important amount of small granules $(39.80 \pm 1.90 \%)$ while $\mathrm{V}_{62}$ counted the slightest $(9.00 \pm 0.79 \%)$.

Concerning granules (small and large sizes) shape (Figure 1), the whole starch varieties granules were irregularly ovoid $(\mathrm{Ov})$ and conical (Con) with a truncated (T) side bearing a centric/eccentric pin-hole $(\mathrm{H})$. Their surfaces were in aggregate smooth (Sth) except for some granules of $\mathrm{V}_{62}$ and $\mathrm{V}_{65}$ starches which were rough $(\mathrm{R})$ or crumpled. The variety $\mathrm{V}_{65}$ also presented granules with furrows $(\mathrm{F})$.

\section{Physicochemical characteristics}

Considering physicochemical characteristics, Duncan's test of the ANOVA underlined significant differences between starch varieties, as far as amylose and amylopectin contents (Table 2). Both characteristics negatively correlated $(\mathrm{r}=$ $0.894)$ were ranged respectively from $14.35 \pm$ $2.73\left(\mathrm{~V}_{63}\right)$ to $25.92 \pm 2.78 \%\left(\mathrm{~V}_{65}\right)$ and from $85.65 \pm 2.09\left(\mathrm{~V}_{65}\right)$ to $74.08 \pm 1.45 \%\left(\mathrm{~V}_{63}\right)$. The other varieties showed intermediary values for both amylose $(16.39 \pm 2.09$ to $19.71 \pm 2.34 \%)$ and amylopectin (80.29 \pm 2.55 to $83.61 \pm 2.56 \%$ ).

As for the $\mathrm{pH}(5.42 \pm 0.92)$ and the moisture $(13.19 \pm 1.10 \%)$, the studied starches showed no significant differences.

\section{Functional properties}

All the starches showed the same profile of Gaussian curve with a swelling peak (maximum of swelling power) at $80{ }^{\circ} \mathrm{C}$ for $\mathrm{V}_{62}$ and $\mathrm{V}_{71}$ varieties. The other varieties registered their maximum of swelling at $85^{\circ} \mathrm{C}$ (Figure 2). However, statistical analyses have revealed significant $(\mathrm{p}<0.0001)$ differences between the maximum of swelling power (SP) of starches (Figure 2). The variety $\mathrm{V}_{53}$ recorded the most important swelling power $(32.47 \pm 0.01 \mathrm{~g} / \mathrm{g})$ compared to $\mathrm{V}_{23}(24.53 \pm$ $0.01 \mathrm{~g} / \mathrm{g}$ ). The other varieties showed intermediary values ranging from $26.32 \pm$ $0.01\left(\mathrm{~V}_{65}\right)$ to $29.41 \pm 0.01 \mathrm{~g} / \mathrm{g}\left(\mathrm{V}_{63}\right)$.

The solubility profile showed the same tendency for all the starches (Figure 3). Indeed, the solubility of all the starches varieties increased slowly from 50 to $60{ }^{\circ} \mathrm{C}$ and more rapidly until $95{ }^{\circ} \mathrm{C}$. The maximum of solubility (at $95{ }^{\circ} \mathrm{C}$ ) varied significantly (p $<0.0001$ ) from a starch to another. Variety 
$\mathrm{V}_{53}$ showed the highest value $(80.70 \pm 0.01 \%)$ while $\mathrm{V}_{65}$ had the lowest $(66.30 \pm 0.01 \%)$ at the same temperature $\left(95^{\circ} \mathrm{C}\right)$.

The water absorption capacity was relatively strong for the whole starches and also varied significantly from a starch to another $(\mathrm{p}<0.0001)$ as shown on Figure 4. The variety $\mathrm{V}_{53}$ recorded the highest capacity $(122.43 \pm 1.23 \%)$ and $V_{63}$, the lowest (104.84 $\pm 2.02 \%)$.

Concerning the starch gels syneresis, all of them registered zero percent $(0.00 \%)$ the first day $\left(\mathrm{J}_{0}\right)$ at both +4 and $-15{ }^{\circ} \mathrm{C}$, and then rose up until the fourth week (Figures $5 \mathrm{~A}$ and 5B). At $4{ }^{\circ} \mathrm{C}$, the increasing in the syneresis was pronounced after the first week for the whole starches varieties except for $\mathrm{V}_{23}(0.00$ to $2.65 \%)$ and $\mathrm{V}_{63}(0.00$ to $0.60 \%)$. However, a relative stabilization of syneresis was noticed between the third and the fourth week of storage at $+4{ }^{\circ} \mathrm{C}$ and $-15^{\circ} \mathrm{C}$, for all the starches varieties (Figure 5A and 5B).

All the starch gel showed their maximum of clarity on the first day $\left(\mathrm{J}_{0}\right)$ and then decreased continuously until the fourth week of storage at $4{ }^{\circ} \mathrm{C}$ (Figure 6). Among all starches, the $\mathrm{V}_{53}$ variety showed, the clearest gel during the experimental period since it decreased from $85.85 \pm 1.00 \%$ the first day to $55.10 \pm 1.00 \%$ the fourth week. The maximum of clarity at $\mathrm{J}_{0}$ was significantly different $(p<0.0001)$ from a starch variety to another and ranged from $34.75 \pm 1.00 \%$ for $\mathrm{V}_{65}$ to $85.85 \pm 1.00 \%$ for $\mathrm{V}_{53}$. Intermediary values varied between $44.90 \pm 1.00$ and 63.00 $\pm 1.00 \%$.

Table 1: Starch granules distribution.

\begin{tabular}{ccc}
\hline Varieties & Granules sizes extent of variation $(\mu \mathrm{m})$ & $\begin{array}{c}\text { Proportion of small } \\
\text { granules }(\%)\end{array}$ \\
\hline $\mathrm{V}_{23}$ & $4.22-24.07$ & $29.60 \pm 2.50 \mathrm{~b}$ \\
$\mathrm{~V}_{52}$ & $4.60-24.08$ & $17.60 \pm 2.50 \mathrm{c}$ \\
$\mathrm{V}_{53}$ & $6.46-\mathbf{2 9 . 8 6}$ & $09.20 \pm 1.09^{\mathrm{e}}$ \\
$\mathrm{V}_{62}$ & $6.15-23.66$ & $9.00 \pm 0.79 \mathrm{e}$ \\
$\mathrm{V}_{63}$ & $6.45-28.63$ & $13.20 \pm 1.30 \mathrm{~d}$ \\
$\mathrm{~V}_{65}$ & $\underline{2.81}-25.47$ & $\mathbf{3 9 . 8 0} \pm \mathbf{1 . 9 0 a}$ \\
$\mathrm{V}_{71}$ & $5.41-25.22$ & $16.40 \pm 1.50 \mathrm{c}$
\end{tabular}

Data are represented as means \pm SEM $(n=3)$. Mean with different letters in the same ; row are statistically different $(\mathrm{p}<0.05)$ according to Duncan's test. Legend: In bold, highest values; underlined, the weakest.

Table 2 : Physicochemical characteristics.

\begin{tabular}{ccccc}
\hline Varieties & Moisture $(\%)$ & $\mathrm{pH}$ & Amylose $(\%)$ & Amylopectin $(\%)$ \\
\hline $\mathbf{V}_{\mathbf{2 3}}$ & $12.90 \pm 0.40 \mathrm{a}$ & $5.49 \pm 0.10 \mathrm{a}$ & $17.67 \pm 1.75 \mathrm{c}$ & $82.33 \pm 3.00 \mathrm{a}$ \\
$\mathbf{V}_{\mathbf{6 5}}$ & $12.65 \pm 0.43 \mathrm{a}$ & $4.51 \pm 0.31 \mathrm{a}$ & $\mathbf{2 5 . 9 2} \pm \mathbf{2 . 7 8 a}$ & $\underline{74.08 \pm 1.45 \mathrm{c}}$ \\
$\mathbf{V}_{\mathbf{5 2}}$ & $12.60 \pm 0.20 \mathrm{a}$ & $5.61 \pm 0.13 \mathrm{a}$ & $16.39 \pm 2.09 \mathrm{c}$ & $83.61 \pm 2.56 \mathrm{a}$ \\
$\mathbf{V}_{\mathbf{5 3}}$ & $13.45 \pm 0.35 \mathrm{a}$ & $5.59 \pm 0.20 \mathrm{a}$ & $16.53 \pm 2.47 \mathrm{c}$ & $83.47 \pm 2.76 \mathrm{a}$ \\
$\mathbf{V}_{\mathbf{6 2}}$ & $14.50 \pm 0.29 \mathrm{a}$ & $5.51 \pm 0.20 \mathrm{a}$ & $19.71 \pm 2.34 \mathrm{~b}$ & $80.29 \pm 2.55 \mathrm{~b}$ \\
$\mathbf{V}_{\mathbf{6 3}}$ & $13.05 \pm 0.51 \mathrm{a}$ & $5.72 \pm 0.10 \mathrm{a}$ & $14.35 \pm 2.73 \mathrm{~d}$ & $\mathbf{8 5 . 6 5} \pm \mathbf{2 . 0 9 a}$ \\
$\mathbf{V}_{\mathbf{7 1}}$ & $13.50 \pm 0.62 \mathrm{a}$ & $5.53 \pm 0.21 \mathrm{a}$ & $17.61 \pm 2.35 \mathrm{c}$ & $82.39 \pm 2.65 \mathrm{a}$ \\
\hline
\end{tabular}

Data are represented as means \pm SEM $(n=3)$. Mean with different letters in the same row are statistically different $(\mathrm{p}<0.05)$ according to Duncan's test. Legend: In bold, highest values; underlined, the weakest. Amylose and Amylopectin content are on the basis of dry mater. 

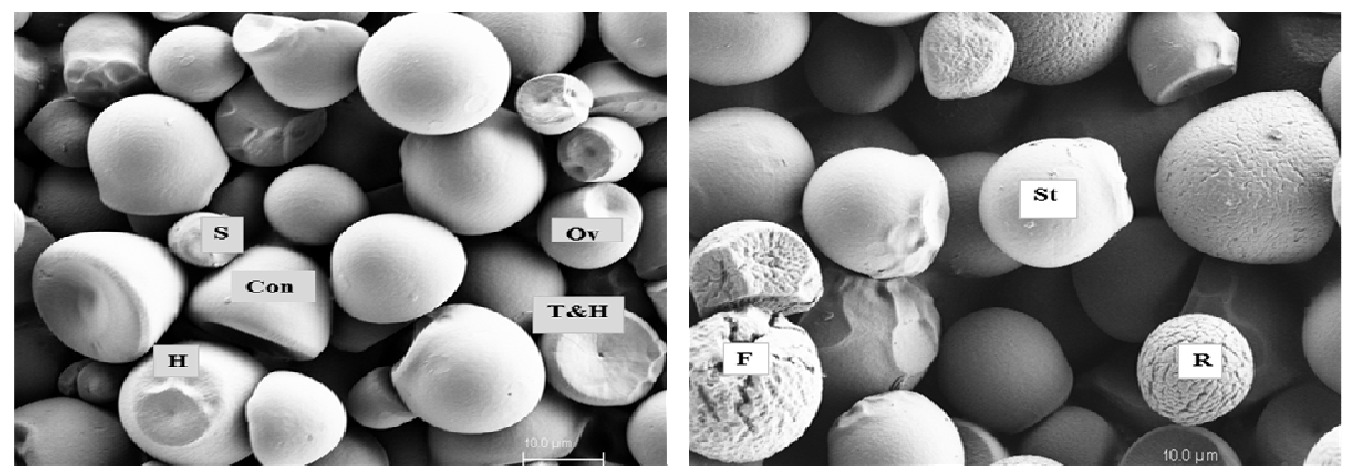

Figure 1: Starch granules morphology.

Legend: S; small granule, Con: conical, F: furrow, $\mathbf{H}$ : centric/eccentrics hilum, O: ovoid, R: rough granule, T\&H: truncated side bearing a hilum, Sth: smooth granule.

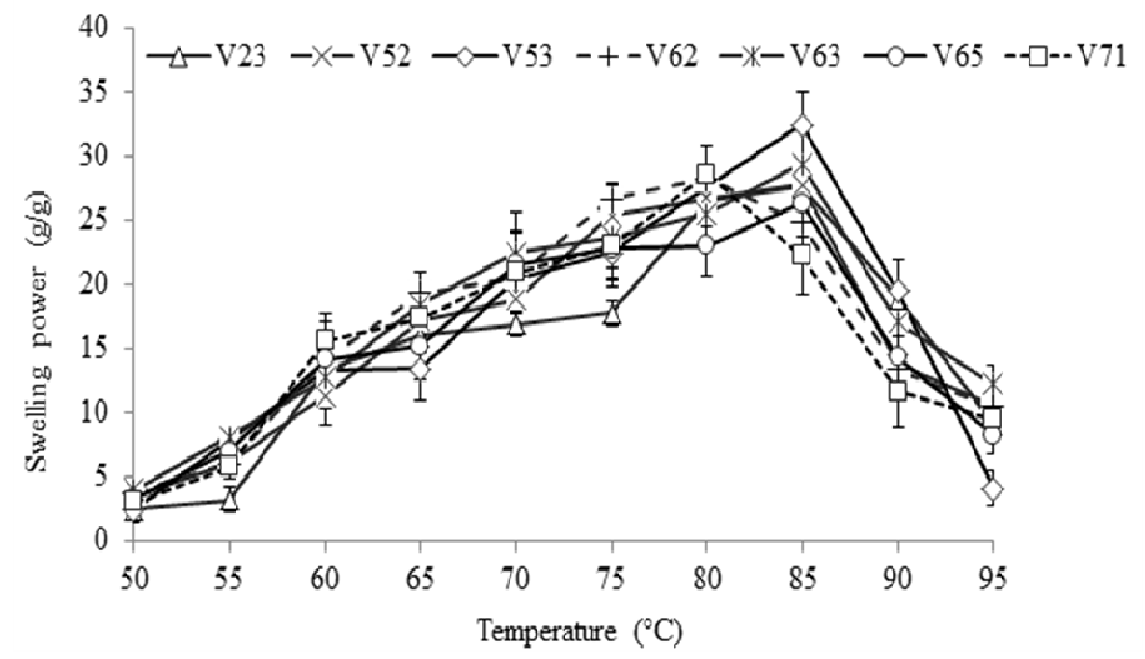

Figure 2: Swelling power evolution as function to the temperature.

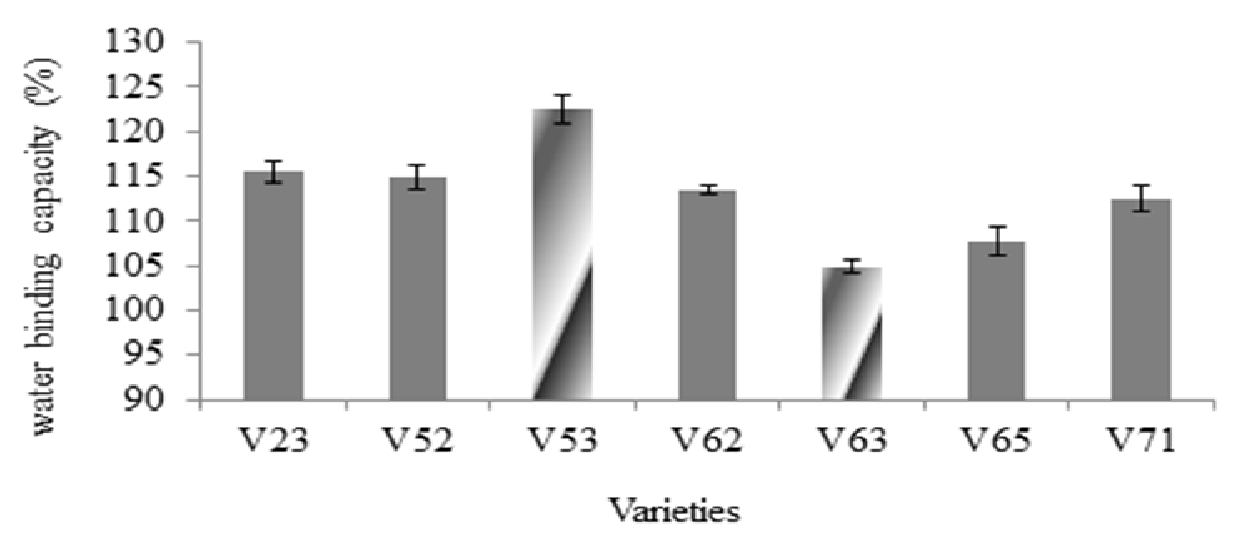

Figure 3: Solubility evolution as function to the temperature. 


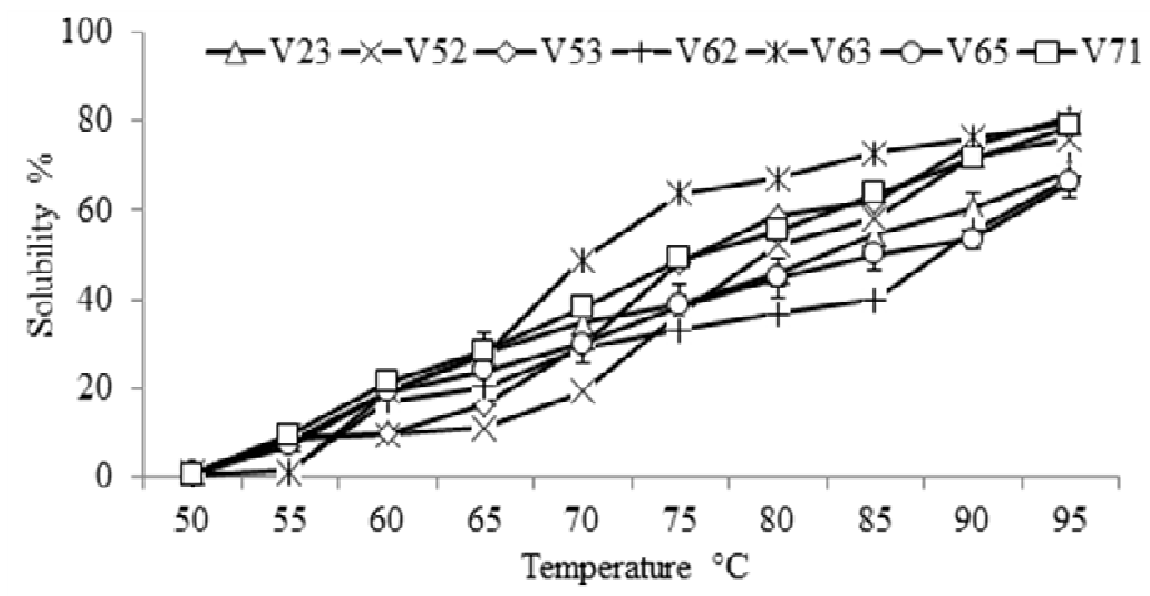

Figure 4: Water absorption capacity of cassava starches varieties.

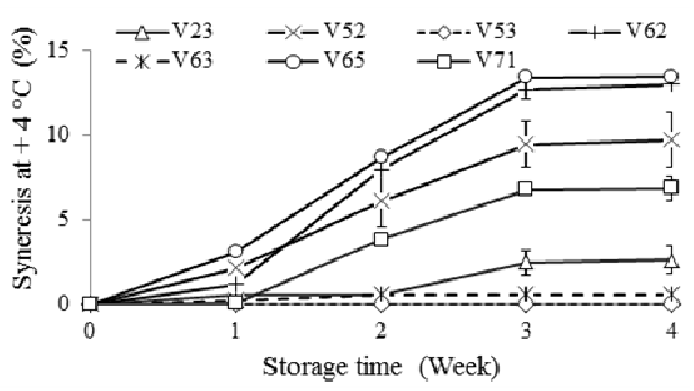

Figure 5A:

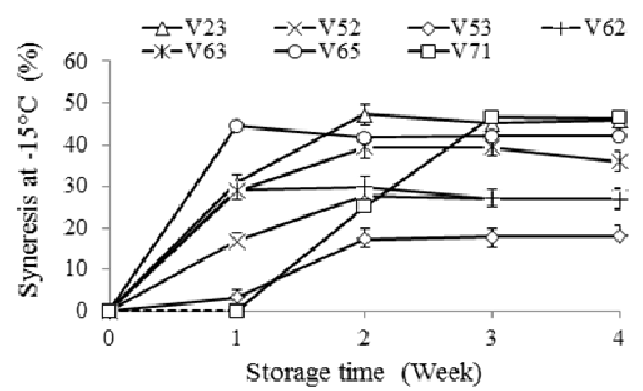

Figure 5B:

Figure 5A: Evolution of the gel syneresis during storage at $+4{ }^{\circ} \mathrm{C}$.

Figure 5B: Evolution of the gel syneresis during storage at $-15^{\circ} \mathrm{C}$.

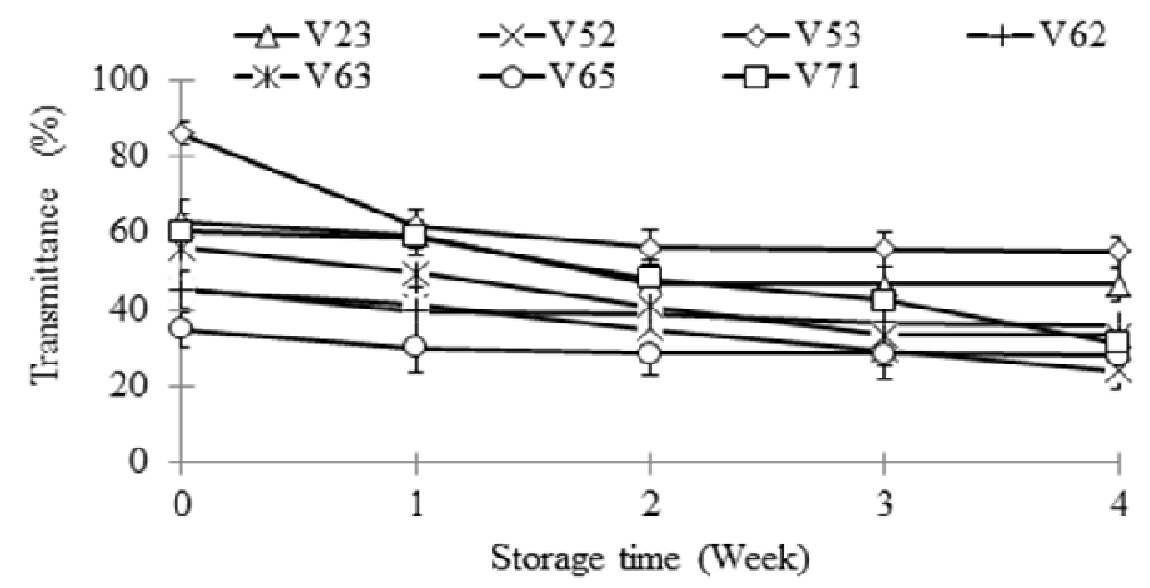

Figure 6: Evolution of the starch gel clarity during storage at $+4{ }^{\circ} \mathrm{C}$. 


\section{DISCUSSION}

Starch contributes greatly to the textural properties of many foods and has many industrial applications (Aviara et al., 2010). This contribution could depend of granules characteristics (morphology, composition and intra-structure) which would induce functional properties (Singh et al., 2003; Massaux et al., 2006). For instance, the more the amount of small granules, the more the resistance of starch to chemical and enzymatic reactions (Massaux et al., 2006). Moreover, this kind of starch could constitute an interesting raw material in cosmetic and pharmaceutical industries as dusting powder, pills coating, tablet binder and dispersing/dusting agent (FAO, 1998). It could also be used as fat substituent in some dietetic foods. Hence, on the basis of their amounts of small granules, the variety $\mathrm{V}_{65}$ and in a lesser extent the variety $V_{23}$ could be recommended for cosmetic, pharmaceutical and food (dietetic) industries to serve these previous purposes as equivalent or substitute of rice starch which is currently used (FAO, 1998). The other starch varieties could be involved in plastic film manufacturing because of their high amount of large granules (> $10 \mu \mathrm{m})$. This involvement would induce the biodegradation of the plastic film (Massaux et al., 2006).

If the small strongest granules confer resistance to starches, the large ones would react rapidly with water (Massaux et al., 2006). This fact could explain the higher water absorption capacity observed for the whole starch varieties which were essentially composed of large $(>10 \mu \mathrm{m})$ granules. Moreover, when dispersed in cold water, starches water absorption capacity (WAC) depends on the associative forces among starch components (Aryee et al., 2006). This would suggest that the whole cassava starch molecules possessed relatively weak interassociative force. This property is useful in pharmaceutical industry for starches involved in pills manufacturing. Indeed, the WAC of the whole varieties was superior to that $(82.10$ to $97.70 \%$ ) of the corn starch generally involved in pills (Singh and Singh, 2006). The suggested inter-associative force weakness, but also the high amount of amylopectin in the whole starches, could also justify their rapid gelatinization that begins at $50{ }^{\circ} \mathrm{C}$ and their high swelling degree (Singh et al., 2003; Sasaki and Matsuki, 1998; Wickramashinge et al., 2009). Indeed, Wickramasinghe et al. (2009) reported that low amylose starch granules swell rapidly when heated with excess water. It is important recalling here that varieties $\mathrm{V}_{62}$ and $\mathrm{V}_{65}$ contained rough granules with furrow (for $\mathrm{V}_{65}$ ). This property would also be taken into account in the understanding of both the rapid gelatinization and swelling peak reaching. Indeed, Massaux et al. (2006) presume damaged granule to rapid absorption than the safe ones. Above all, it might be noticed that such low temperature of gelatinization (beginning at $50{ }^{\circ} \mathrm{C}$ ) was inferior to that $\left(60^{\circ} \mathrm{C}\right)$ reported by Abegunde et al. (2012) for some cassava starch and Zuluaga et al. (2007) concerning corn starch $\left(70{ }^{\circ} \mathrm{C}\right)$. Hence, all the studied starch varieties could be exploited in chemical industry and metallurgy (FAO, 1998) mainly for glue and adhesive production in substitution of corn starch which is currently used. This exploitation would be more economical for the industrials of high cassava producing countries because this root is more accessible and cheaper than corn. Additionally, they would reduce the energy cost though the starches would not necessitate high heating temperature to obtain glue and adhesive. More than chemical exploitation, the studied starches mainly those of varieties $\mathrm{V}_{62}$ and $\mathrm{V}_{71}$ with their highest swelling degree at a low temperature $\left(80^{\circ} \mathrm{C}\right)$ could be used as texturing in sausage in order to avoid high heating and then preserve meat nutritive elements from alteration (Hendrick et al., 1994). The whole starches could also occur in household and food industry as texture agent for soups, sauces, puddings and gravies.

The physical appearance of a starch gel is important for subsequent uses with 
preference for particular clarity (Singh et al., 2003) so that the resulting product would conserve its original color. Moreover, such uses of starch would also necessitate its suitability for being stored a long time at ambient or cold temperature. Consequently, the retrogradation phenomena, which is defined as the molecular interaction (hydrogen bonding between starch chains) after cooling of the gelatinized starch paste (Hoover, 2000) might be taken into account. During retrogradation, amylose forms double helical associations of about 40-70 glucose units (Jane and Robyt, 1984) whereas amylopectin crystallization occurs by association of the outermost short branches (Ring, 1987). This molecular reorganization could justify the starch gels behavior in the present study since the highest clarity and the lowest syneresis were observed the first day (ambient temperature) and then decreased (clarity) and increased (syneresis) before a relative stabilization. The whole clarity of the studied starches was superior to those reported by Nuwamanya et al. (2011) for some cereals (4.62 to $22.05 \%$ ), tubers (22.75 to $45.40 \%$ ) and cassava (46.08 to $55.02 \%)$. This fact could be due to the lowest impurity content (fat and protein) of cassava starches. However, the higher the amylose content was, the lower is the clarity and the higher the syneresis would be, as reported by Davies (2008). Hence, the starch of varieties $V_{23}, V_{52}$, $\mathrm{V}_{53}, \mathrm{~V}_{63}$ and $\mathrm{V}_{71}$ (in descending order) could preferentially be exploited in textile industry (FAO, 1998; Nuwamanya et al., 2011) where high clarity is requested. They could also occur in food industry (mainly varieties $\mathrm{V}_{23}$, $\mathrm{V}_{53}$ and $\mathrm{V}_{71}$ ) in substitution of Arabic gum and gelatin, and permit derivate-foods to be stored at $4{ }^{\circ} \mathrm{C}$ for three and at least four weeks without significant opacity. They could also be used in bakery (icing sugar, custards and icing), in frozen foods (fruits filling, syrup and cream-based products) and in dairy products (yoghurt, cheese and puddings). Concerning varieties $\mathrm{V}_{52}$ and $\mathrm{V}_{63}$, they might not be involved in products which storage time exceeded one week.

Above all, it is interesting to underline that the whole cassava starches varieties showed syneresis at +4 and at $-15{ }^{\circ} \mathrm{C}$ in conformity with those of waxy rice and corn starch reported by Sanchez et al. (2010) on the first day. Furthermore, varieties $\mathrm{V}_{53}$ and $\mathrm{V}_{63}$ could be involved successfully in food (cream, soup and syrup), which would be stored at +4 ${ }^{\circ} \mathrm{C}$ for up to four weeks, and $\mathrm{V}_{71}$ in food (ice cream) suitable to be stored at $-15{ }^{\circ} \mathrm{C}$ for less than a week. These varieties could then occur as potato and waxy starches substitute or equivalents which are mostly used in food industry (Hughes, 1998) despite their high cost.

\section{Conclusion}

All the starches varieties of the present study could be exploited (with less cost) in chemical industry for glue and adhesive manufacturing because of their relative low gelatinization temperature. They could also occur in textile industry mainly as varieties $\mathrm{V}_{23}, \mathrm{~V}_{52}, \mathrm{~V}_{53}, \mathrm{~V}_{53}, \mathrm{~V}_{63}$ and $\mathrm{V}_{71}$ are concerned, on the basis of their relatively high clarity. Moreover, $\mathrm{V}_{23}, \mathrm{~V}_{53}$ and $\mathrm{V}_{71}$ could be useful in cosmetic and pharmaceutical industries due to their most important amount of small granule. The food industry could involve the starches of the varieties $V_{23}, V_{53}$ and $V_{71}$ in several preparations (ice-sugar, cream, soup, sausage, syrup, etc) because of their high clarity and low syneresis which would respect and permit products long shelf life without color alteration.

\section{REFERENCES}

Abegunde OK, Mu T-H, Arogundade LA, Deng F-M, Chen J-W. 2012. Physicochemical characterization of starches from some Nigerian and Chinese roots and tubers. Afr. J. Food Sci., 6: 317329.

AOAC. 1990. Official Methods of Analysis. Association of Official Analytical Chemists: Washington DC.; 152-154. 
Aryee F, Oduro I, Ellis W, Afuaka J. 2006. The physicochemical properties of flour samples from the roots of 31 varieties of cassava. Food Control, 17: 916-922.

Aviara NA, Igbeka JC, Nwokocha LM. 2010. Effect of dry drying temperature on physicochemical properties of cassava starch. Int Agrophysics., 24: 219-225.

Banks W, Greenwood CT. 1975. Starch and its Components. Edinburgh University Press; 270-273.

Benesi IRM, Labuschagne MT, Dixon AGO, Mahungu NM. 2004. Stability of native starch quality parameters, starch extraction and root dry matter of cassava genotypes in different environments. $J$. Sci Food Agric., 84: 1381-1388.

Cereda MP, Takahashi M. 1996. Cassava wastes: Their characterization, uses and treatment in Brazil. In Cassava Flour and Starch: Progress in Research and Development, Dufour D, O'Brien GM, Best R (eds). CIAT Publication $n^{\circ} 271$ : Cali, Colombia; 221-232.

Davies EM, Maryke TL, Elizma K, Ibrahim RMB, John DKS. 2008. Some properties of starches from cocoyam (Colocasia esculenta) and cassava (Manihot esculenta Crantz.) grown in Malawi. Afr. J. Food Sci., 2: 102-111.

FAO 1998. Le marché boude les amidons tropicaux. http://www.fao.org.

FAO 2006. Focus: Le marché de l'amidon valorise le manioc. p. 4. www.fao.org/ ag/fr/magazine/0610sp1.htm

FAO/IFAD 2004. The Global Cassava Development Strategy: Cassava for livestock feed in sub-Saharan Africa. Olumide O. Tewe and NeBambi Lutaladio. p 76 Rome.

Graig SAS, Maningat CC, Seib PA, Hoseney RC. 1989. Starch paste clarity. Cereal Chem., 66: 173-182.

Hendrick HB, Aberle ED, Judge MD, Forrest JC. 1994. Principles of Meat Science. Freeman WH and Co: San Francisco; 198.
Hoover R. 2000. Composition, moleculae structure, and physicochemical properties of tuber and root starches: a review. Carbohydr. Polym., 45: 253-267.

Hughes E, Mullen, Tray DJ. 1998. Effect of fat level, tapioca starch and whey protein on frankfurters formulated with 5 and 12 per cent fat. Meat Sci., 48: 169-180.

Jane JL, Robyt JF. 1984. Structure studies of amylose $\mathrm{V}$ complexes and retrogradaded amylose by action of alpha amylase, a new method for preparing amylodextrins. Carbohydr. Res., 132: 105-110.

Jarvis CE, Walker JRL. 1993. Simultaneous, Rapid, Spectrophonic Determination of Total Starch, Amylose and Amylopectin. J. Sci Food Agric., 63: 53-57.

Koua GYA, Megnanou R-M, Kra KAS, N'Zue B, Tian Bi DR, Akpa EE, Niamké SL. 2012. Biochemical characterization of new varieties of yellow colored pulp cassava flours from Côte d'Ivoire. $J$. Appl. Biosci., 53: 3760-3772.

Li JY, Yeh AI. 2001. Relationship between thermal, rheological characteristics and swelling power for various starches. $J$. Food Eng., 50: 141-148.

Massaux C, Bodson B, Lenartz J, Sindic M, Sinnaeve G, Dardenne P, Falisse A, Deroanne C. 2006. L'amidon natif de blé: Un composé naturel à valoriser par la connaissance de ses propriétés technofonctionnelles? Le Livre Blanc «Céréales» F.U.S.A. et CRA-W Gembloux. 6 p.

Nuwamanya E, Baguma Y, Wembabazi E, Rubaihayo P. 2011. A comparative study of the physicochemical properties of starches from root, tuber, and cereal crops. Afr. J. Biotechnol., 10: 1201812030.

Ring SG, Colonna P, l'Anson KJ, Kalichevsky MT, Miles MJ et al. 1987. The gelation crystallization amylopectin. Carbohydr. Res., 162: 227-293.

Sánchez T, Dufour D, Moreno IX, Ceballos H. 2010. Comparison of pasting and gel stabilities of waxy and normal starches 
from potato, maize, and rice with those of a novel waxy cassava starch under thermal, chemical, and mechanical stress. J. Agric. Food Chem., 58: 5093-5099.

Sasaki T, Matsuki J, 1998. Effectof wheat starch structure on swelling power. Cereal Chem., 75: 525-529.

Schoch TJ. 1968. Effect of freezing and cold storage on pasted starches. In The Freezing Preservation of Food (vol. 4), Tressler DK, Van Arsdel, Copley MJ (eds). The AVI Publishing co., Westport Connecticut; 45-56.

Singh J, Singh N, Sharma TR, Saxena SK. 2003. Physicochemical, Rheological and cookie making properties of corn and potato flours. Food Chem., 83: 387-393.

Singh JO, Singh McCH. 2006. Physicochemical and morphological characteristics of New Zealand Taewa (Maori potato) starches. Carbohydr. Polym., 64: 569-581.
Sosulski FN. 1962; The centrifuge method for determining starch absorptivity in hard red spring wheat. Cereal Chem., 39: 344346.

Wickramashinge HAM, Takigawa S, Yamauchi H, Noda T, Matsuura-Endo C. 2009. Comparative analysis of starch properties of different root and tuber crops of Sri Lanka. Food Chem., 112: 98103.

Zuluaga M, Baena Y, Mora C, Ponce D'Leon L. 2007. Physicochemical Characterization and Application of yam (Dioscorea cayenensis-rotundata) Starch as a Pharmaceutical Excipient. Starch/Starke., 59: 307-317. 